\title{
Assessment of Medical Students' Readiness for Self-directed Learning
}

\section{Hani S. Atwa}

Faculty of Medicine, Suez Canal University, Egypt and IbnSina National College for Medical Studies, Saudi Arabia

Received :January 2016Accepted : March 2016

\begin{abstract}
Background:Importance of self-directed learning (SDL) has been discussed over a long time. More recently, SDL has been described as the most effective mode of learning for individuals in the information age as it is the way for coping with the constant changes in knowledge.Objective: This study aimed at exploring the SDL readiness of the students of the second year undergraduate medical students. Methods:The study was a descriptive cross-sectional one conducted at IbnSina National College for Medical Studies (ISNC) on all the second year medical students during the academic year 2014-2015. We used the self-directed learning readiness scale (SDLRS) developed by Fisher et al (2001) which contained 40 items grouped under 3 sub-scales: Self-management, Desire for Learning, and Self-control. Descriptive statistics together with regression analysis were applied, using SPSS v.20.Results:The mean score for students in SDL readiness was 159.25 (range: 117 to 193 ), with $76.2 \%$ of students who got scores $\geq 150$ and $23.8 \%$ of them who got scores $<150$. Among three subscales, "Self-control" got the highest mean score (4.15) followed by "Desire for Learning" (4.07), while "Self-management" got the lowest mean score (3.69) on a 5-point scale. Females got higher SDLRS scores than males. There was a positive linear relationship between GPA and SDLRS score. Conclusion:Studentsin ISNC showed a satisfactory degree of readiness for self-directed learning, which was positively related to the academic achievement represented by GPA. Females showed significantly more readiness than males.
\end{abstract}

Keywords: Self-directed learning, IbnSina National College in Jeddah, SDLRS.

Corresponding author: Dr. Hani Atwa,. E-maildoctorhani2000@yahoo.com._Tel: +201224576171, +966593763061 | Fax: +20643227426 |

\section{Introduction}

Self-directed learning (SDL) has been used in adult education to indicate several concepts. Among those concepts are autonomous learning, self-direction in learning, self-regulated learning, independent learning, self-education and directed self-learning 2,3 .

Guglielmino $^{4}$ defined the self-directed learner as the "one who exhibits initiative, independence, and persistence in learning; one who accepts responsibility for his or her own learning and views problems as challenges, obstacles; one who is capable of selfdiscipline and has a high degree of curiosity; one who has a strong desire to learn or change and is self-confident; one who is able to use basic study skills, organize his or her time and set an appropriate pace for learning, and to develop a plan for completing work; one who enjoys learning and has a tendency to be goal-oriented".

Moreover, self-directed learners are resourceful $^{5-7}$ and can effectively locate resources whenever they need them. They have the ability to engage in activities that require self-dependence, set future goals and measure their success and use their critical thinking

Vol. 36 No. 1 January 2018


skills ${ }^{6-8}$. In addition, they can overcome obstacles,face failures and continuously seek improvement ${ }^{6,7,9}$. The importance of SDL has been discussed over a long time. Knowles ${ }^{10}$ described SDL as "a means of survival for the human race living in a new world". Moreover, SDL is of special importance for college students, especially medical students, who are required to be active learners and pursue learning on their own at any time and placeto cope with the everchanging knowledge ${ }^{11,12}$.

SDL is considered by the American Board of Medical Specialties, the Royal College of Physicians and Surgeons of Canada, and the World Federation for Medical Education as a professional characteristic that should be evaluated in the training of physicians ${ }^{13-15}$.

Assessment of students' readiness is an initial step in facilitating and planning for self-directed learning ${ }^{16}$ This assessment will indicate the extent to which the students possess the abilities and personality characteristics necessary to pursue self-directed learning ${ }^{17}$.

The Medicine program at ISNC employs systems-based modules and PBL in its first three (basic sciences) years. Certain topics in each module are taught through PBL, which requires self-directed learning by the students. Some other topics are left for the students, who are expected to spend some time studying such topics independently (Independent Learning or IDL). Students then come to present the topics in front of the relevant subject area expert and other students, followed by a 15-minute time for group discussion. Students are expected to be self-learners in order to do well in a wide range of educational activities.

This study aimed at investigating the levels of readiness for SDL as a first step for observing trends as they progress in the years of study. Results of this study can be used by the educators who can adjust instruction to the level of SDL readiness of their students.

\section{Methods}

This is a descriptive, cross-sectional study that was conducted at ISNC during the academic year 2014-2015. Before starting the study, an ethical approval has been obtained from the research ethics committee of ISNC.

All the students of the second year of Medicine program were included in the study $(n=306)$. The second year is the actual first year of the Medicine program, as the first year is a preparatory one that belongs to all the four programs at ISNC, and the self-directed learning activities are not highlighted in this preparatory year.

The self-directed learning readiness scale (SDLRS) was developed by Fisher et $a l .{ }^{(1)}$.The SDLRS has 40 items grouped under 3 sub-scales: self-management (13 items), desire for learning (12 items), and self-control (15 items). Students were requested to respond to each item on a 5point Likertscale (where $5=$ strongly agree, $4=$ agree, $3=$ unsure, $2=$ disagree, and $1=$ strongly disagree). Four items (items 3, 11, 20, and 40) were scored in a reverse manner as they were negatively worded.

The maximum possible score for the whole scale is 200 (40 items on a scale from 0 to 5). According to Fisher et al. ${ }^{(1)}$, scores equal to or more than 150 were considered to indicate readiness for selfdirected learning.

The SDLRS questionnairewas translated by experts in medical education into Arabic, in order to make it easily understandable for the students whose mother tongue is Arabic. After translation, Cronbach's alpha was performed to assess its internal consistency. Validity was established through confirmatory factor analysis. In addition, face validity wasestablished by revision of the translated questionnaireby 
experts from the Medical Education Unit at ISNC.

The SDLRS questionnaire was administered anonymously to the students and they were given the liberty not to participate in the study without any consequences.

\section{Ethical considerations}

The study was approved by the Human Ethics Committee of IbnSina National College for Medical Studies (IHEC Ref No. : H-01-13102014). Questionnaire was anonymous, did not contain any critical questions, and confidentiality of the data were maintained.

\section{Statistical analysis}

Data was collected and entered to Microsoft Excel 2010. Mean scores of the individual items and the three subscales were compared across male and female students. SDLRS scores of those students were correlated with their previous Grade Point Average (GPA) (the GPA of the previous year) and gender using linear regression analysis. For statistical analysis, IBM SPSS v. $20^{(18)}$ was used. P-values< 0.05 were considered statistically significant.

\section{Results}

The response rate was $78 \%(\mathrm{n}=239 ; 106$ males and 133 females). Internal consistency was established through Cronbach's alpha coefficient. Alpha values ranged from 0.608 for "Desire for Learning" to 0.852 for "Self-control". For the scale as a whole, alpha coefficient was 0.879 .

Validation of the scale was established through confirmatory factor analysis (Table 1), which showed heavy loading on one factor for all the components of the scale. Gender and GPA neither loaded on the same factor with the components of the scale nor with each other.

\section{Discussion}

Our study aimed at exploring the readiness of the second year medical students at ISNC for self-directed learning as an important skill for medical students, especially at those schools implementing innovative curricula with problem-based learning and other selflearning strategies ${ }^{19}$.

The SDLRS used was tested for construct validity and internal consistency, and very satisfactory values were obtained. This was an important step, as the scale was translated from English to Arabic by the author.

Most of the items in the scale had high mean scores, which is consistent with the study by Fisher et al. ${ }^{1}$ and better than the results reported by Abraham et al. ${ }^{19}$ and Stewart $^{20}$. This contributed to the high overall mean SDLRS score for the studied population.

Regarding the "Self-management" subscale, although the students had the highest mean score in prioritizing their work, which is one of the time management principles ${ }^{21}$, their mean scores denote that they have a problem in managing their time effectively. This discrepancy between the high ability to decide which work is more important (prioritizing tasks) and low ability to manage time may be due to the multiplicity of the educational activities they have and the busy schedule. The nature and volume of workload typically encountered by medical students was studied by Zamaksharyet $a l^{22}$, who stressed on the importance of time management to deal with such workload. Regarding the "Desire for Learning" subscale, the item stating "I want to learn new information" had the highest score, while the item stating "I enjoy studying" got the lowest score in this subscale. This indicates that the students are eager to learn new information and are expected to be ready for practicing self-directed learning. However, the problem is that they find studying boring. Students most probably get bored of studying things out of context. This 
seems to be a good opportunity for medical schools to raise the awareness of their students about self-directed learning and the joy of self-dependence in finding information and reflecting it on the context. Guglielmino ${ }^{4}$ identified a number of characteristics of self-directed learners; joy of learning is one of them. Regarding "Self-control" subscale, the item stating "I have high personal expectations" had the highest mean score (4.46). This is expected of medical students everywhere, who are known to be ambitious and having high values and expectations for themselves. This score is similar to that found by Stewart ${ }^{20}$. On the other hand, students reported lowest score in controlling their own social life. This may be due to the nature of medical subjects, which needs much time for studying, and medical students may feel that they have to spend all their time studying such subjects.

More than three fourths of the students had SDLRS equal to or higher than 150 (out of 200), with a mean overall score of 159.25. This indicates an expected readiness of our students for self-directed learning. Such finding is supposed to help the school provide more opportunities for the students for selfdirected learning. Abraham et $a l^{19}$ reported that around $60 \%$ of students in their study had a similar high score. Using the same scale, Phillips et al, ${ }^{23}$ reported the same overall SDLRS score as ours. Moreover, mean scores for different subscales were similar to ours. Shokaret $\mathrm{al}^{24}$ and Mohammadi and Mahdi $^{25}$, using a different scale, reported similar high scores for readiness for selfdirected learning.

Regarding gender differences in the overall mean score of SDLRS, Phillips et $a l^{23}$ reported higher overall score for females than for males as we found in our study. The difference they found was not statistically significant while our difference was. Similarly, Morris ${ }^{26}$,
Shaikh $^{27}$ Williamset $a l^{28}$ and Monkaresiet $a .^{29}$ found higher mean overall scores for females than males, but the differences were not statistically significant. At ISNC, females are known to be more active and ambitious than males. This can explain the difference in the overall SDLRS score between males and females.

Regression analysis revealed that higher overall SDLRS score for females than males (although statistically significant) cannot be explained by gender itself alone. Other factors; like time available for learning, ability to seek and obtain knowledge, ability to set goals and work toward them; should be considered among other factors in further studies.

On the other hand, regression analysis revealed that high overall SDLRS score for the studied students can be explained by the GPA, as there was a statistically significant linear relationship between both $(p<0.05)$. In contrast to our results, Monkaresiet al. $^{29}$ found that the degree of readiness of students for self-directed learning was not different based on their GPA. However, several other studies showed results that were in agreement with ours.

In a study on undergraduate college students, Long ${ }^{30}$ found a positive relationship between overall GPA and SDLRS scores, concluding that "attitudes toward learning as measured by the SDLRS positively interact with quality of performance (as defined by GPA in school)". Reio ${ }^{31}$ investigated how prior knowledge, self-directed learning readiness, and curiosity were related to learning performance in a classroom and found that "SDLR was by far the most robust predictor of learning performance after the possible confounding effects of age, gender, and ethnicity were controlled". Similarly, Gabrielle et al. ${ }^{32}$ found that increase in higher GPA was associated with increases in the levels of readiness for self-directed learning. In his 
study on engineering undergraduate students, Stewart ${ }^{20}$ found a reliable positive linear trend between SDLRS and GPA. Also, in a four-year study of students in a pharmacy preparation program, Slaughter ${ }^{33}$ found that students with above average SDLRS scores performed better than those with lower scores and had higher GPAs. Vasheet $a l^{(34)}$ found a positive relationship between readiness for self-directed learning and academic performance of medical students.

\section{Conclusion}

In conclusion, medical students in our study showed a satisfactory degree of readiness for self-directed learning. Females showed significantly more readiness than males, but gender difference was not found to be a determinant of readiness for self-directed learning. Academic achievement (represented by GPA) was found to be positivelyrelated to the degree of readiness for self-directed learning.

We suggest that ISNC (and medical schools in general) utilize the readiness of their students for self-directed learning through curricular changes that focus on increasing self-directed learning activities, providing the students with the resources that enable them to practice self-directed learning, and training faculty to tailor learning tasks that encourage students' self-directedness. It is also useful that medical schools do all effort to help students use their readiness for self-directed learning to better manage their learning.Furthermore, the results of this study may be used for counseling or training students with selfdirected learning deficiencies.

\section{Limitations of the study}

Limitations of this study included studying only the second year students. Including premedical students and also students of the higher batches would improve the results and give a better understanding of the readiness of medical students for self-directed learning. One more limitation is using only gender and GPA for regression study. We think that adding more variables like type of precollege education, linguistic abilities, and personality traits would add more value to the study.

Declaration of interest: The author states that there are no conflicts of interest.

Acknowledgement:All thanks to the students who participated in the study and also the administration of ISNC which was of great support.

\section{References}

1. Fisher M, King J, Tague G. Development of a self-directed learning readiness scale for nursing education. Nurse Education Today 2001; 21:516525.

2. Hiemstra R. Self-directed learning lexicon. International journal of selfdirected learning 2004; 1(2):1-6.

3. BrydgesR, Dubrowski A, Regehr G. A new concept of unsupervised learning: directed self-guided learning in the health professions. Academic Medicine 2010; 85(10 Suppl):S49-55.

4. Guglielmino L. Development of the Self-Directed Learning Readiness Scale (Doctoral dissertation, University of Georgia, 1977). Dissertation Abstracts International 1978; 38:6467A.

5. Ponton M, Derrick G, Hall M, Rhea $\mathrm{N}$, Carr P. The relationship between selfefficacy and autonomous learning: the development of new instrumentation. International Journal of Self-directed Learning 2005;2(1).

6. Guglielmino L. Why self-directed learning? International Journal of SelfDirected Learning 2008; 5(1):1-14.

7. Guglielmino L. The case for promoting self-directed learning in formal educational institutions. South African Educational Journal 2013; 10(2):1-18. 
8. Pata K.Modeling spaces for selfdirected learning at university courses. Educational Technology \& Society 2009; 12(3):23-43.

9. Costa A, Kallick B. Why We Need Self-Directed Learners. In: Assessment Strategies for Self-Directed Learning.SAGE Publications Ltd., London, UK 2004.

10. Knowles M. Self-directed learning: A guide for learners and teachers. New York: Association Press 1975.

11. Cohen M. The importance of selfregulation for college student learning. College Student Journal 2012; 46(4):892902.

12. Bulik R, Romero C. The elusive concept of self-directed learning. In: HB Long, Associates, eds. Self-Directed Learning and the Information Age. Shaumberg, Illinois: Motorola University Press 2001.

13. The American Board of Medical Specialties (ABMS). Maintenance of Certification. Available at. http://www.abms.org/Downloads/Publica tions/1-What\%20is\%20MOC.pdf.

(Accessed: November 8, 2015).

14. The Royal College of Physicians and Surgeons of Canada (RCPSC). Skills for the New Millennium. Report of the Societal Needs Working Group. Available 2004, at: http://rcpsc.medical.org/publications/inde x.php. (Accessed: November 10, 2015).

15. World Federation for Medical Education (WFME). Continuing Professional Development of Medical Doctors: WFME Global Standards for Quality Improvement. Available at http://wfme.org/standards/cpd/16continuing-professional-developmentcpd-of-medical-doctors-english/file. (Accessed: April 12, 2016).

16. Klunklin A, Viseskul N, Sripusanapan A, Turale S. Readiness for self-directed learning among nursing students in Thailand. Nursing and Health Sciences 2010; 12(2):177-181.
17. Wiley K. Effects of a self-directed learning project and preference for structure on self-directed learning readiness. Nursing Research 1983; 32:181-185.

18. IBM SPSS Statistics for Windows, v20.0.Armonk, NY: IBM Corp. 2011.

19. Abraham R, Fisher M, Kamath A, Izzati A, Nabila S, Atikah N. Exploring first-year undergraduate medical students' self-directed learning readiness to physiology. Advances in Physiology Education 2011; 35:393-395.

20. Stewart R. Evaluating the selfdirected learning readiness of engineering undergraduates: a necessary precursor to project-based learning. World Transactions on Engineering and Technology Education 2007; 6:59-62.

21. Jackler R. How to be organized and manage time. In: Weiss Roberts L (Ed). The academic medicine handbook-a guide to achievement and fulfilment for academic faculty. New York: Springer 2013;17-25.

22. Zamakshary $\mathrm{M}, \mathrm{Al}$ Tokhais $\mathrm{T}$, Magzoub ME, Elzubeir M. Managing Time. In: Al Alwan I, Magzoub ME, Elzubeir M (Eds.). International Handbook of Medical Education: A Guide for Students. SAGE Publications Ltd., London, UK 2012;89-94.

23. Phillips B, Turnbull B, $\mathrm{He}$ F. Assessing readiness for self-directed learning within a non-traditional nursing cohort. Nurse Education Today 2015; 35:e1-e7.

24. Shokar G. Shokar N, Romero C, Bulik R. Self-directed Learning: Looking at Outcomes with Medical Students. Family Medicine 2002; 34(3):197-200.

25. Mohammadi P, Mahdi Araghi S. The relationship between learners' selfdirected learning readiness and their English for Specific Purposes course accomplishment at distance education in Iran. Studies in Self-Access Learning Journal 2013; 4(2):73-84. 
26. Morris S.The relationship between self-directed learning readiness and academic performance in a nontraditional higher education program (Doctoral dissertation, The University of Oklahoma 1995).

27. Shaikh R. Comparison of readiness for self-directed learning in students experiencing two different curricula in one medical school. Gulf Medical Journal 2013; 2(1):27-31.

28. Williams B, Boyle M, Winship C, Brightwell R, Devenish S, Munro G. Examination of self-directed learning readiness of paramedic undergraduates: A multi-institutional study. Journal of Nursing Education and Practice 2013; 3(2):102-111.

29. Monkaresi H, Abbasi A, Razyani R. Factors Affecting the Self-directed Learning Readiness. European Online Journal of Natural and Social Sciences 2015; 4(4):865-874.

30. Long H. College students' selfdirected learning readiness and educational achievement. In: Long H. B. and Associates (Eds.). Self-directed learning: Consensus and conflict. Norman, OK: Oklahoma Research
Center for Continuing Professional and Higher Education 1991;107-122.

31. Reio T. Prior knowledge, selfdirected learning readiness, and curiosity: Antecedents to classroom learning performance. International Journal of Self-Directed Learning 2004; 1(1):18-25. 32. Gabrielle D, Guglielmino L, Guglielmino P. Developing self-directed learning readiness of future leaders in a military college though instructional innovation. International Journal of SelfDirected Learning 2006; 3(1):24-35.

33. Slaughter R. Experience in the Doctor of Pharmacy Program at Wayne State University increases students' readiness for self-directed learning. Poster session presented at the annual conference of the American Association of Colleges of Pharmacy, Boston, MA 2009.

34. Vashe A, Devi V, Rao R, Abraham R, Pallath V. "Link between self-directed learning readiness and academic performance of medical students". MOOC Innovation and Technology in Education (MITE), IEEE International Conference in Jaipur 2013;130-133 
Table 1: Confirmatory factor analysis of the SDLRS:

\begin{tabular}{|l|l|l|l|}
\hline \multirow{2}{*}{ Components } & \multicolumn{3}{c|}{ Factor Loading } \\
\cline { 2 - 4 } & Factor 1 & Factor 2 & Factor 3 \\
\hline Self-management & 0.78 & - & - \\
\hline Desire for Learning & 0.78 & - & - \\
\hline Self-control & 0.82 & - & - \\
\hline GPA & - & 0.95 & - \\
\hline Gender & - & - & 0.96 \\
\hline GPA: Grade Point Average
\end{tabular}

Table 2 shows the descriptive statistics of the different subscales of the SDLRS. For "Selfmanagement" subscale, the highest mean score was 4.23 (I prioritize my work); while the lowest was 3.05 (I manage my time well). For "Desire for learning" subscale, the highest mean score was 4.53 (I want to learn new information); while the lowest was 2.95 (I enjoy studying). For "self-control" subscale, the highest mean score was 4.46 (I have high personal expectations); while the lowest was 3.66 (I am in control of my life). 
Table 2: Individual Item Mean, Median, and 95\% Confidence Interval for SDL Readiness Scale:

\begin{tabular}{|c|c|c|c|}
\hline Item & Median & Mean & $\begin{array}{c}95 \% \\
\text { Confidence } \\
\text { Interval (CI) }\end{array}$ \\
\hline Self-management: & 4 & 3.69 & $3.62-3.78$ \\
\hline I solve problems using a plan & 4 & 3.71 & $3.56-3.85$ \\
\hline I prioritize my work & 4 & 4.23 & $4.09-4.36$ \\
\hline I manage my time well & 3 & 3.05 & $2.87-3.22$ \\
\hline I have good management skills & 4 & 3.61 & $3.50-3.72$ \\
\hline I set strict time frames & 3 & 3.23 & $3.08-3.38$ \\
\hline I prefer to plan my own learning & 4 & 4.03 & $3.88-4.17$ \\
\hline I am systematic in my learning & 4 & 3.71 & $3.57-3.85$ \\
\hline I am confident in my ability to search out information & 4 & 3.88 & $3.74-4.02$ \\
\hline I set specific times for my study & 4 & 3.85 & $3.69-4.01$ \\
\hline I am self-disciplined & 4 & 3.77 & $3.63-3.92$ \\
\hline I am organized & 4 & 3.48 & $3.30-3.66$ \\
\hline I am methodical & 4 & 3.53 & $3.40-3.66$ \\
\hline I can be trusted to pursue my own learning & 4 & 4.02 & $3.90-4.15$ \\
\hline Desire for Learning: & 4 & 4.07 & $4.02-4.12$ \\
\hline I need to know why & 5 & 4.35 & $4.23-4.47$ \\
\hline I critically evaluate new ideas & 3 & 3.43 & $3.28-3.56$ \\
\hline I learn from my mistakes & 4 & 4.32 & $4.20-4.44$ \\
\hline I am open to new ideas & 5 & 4.41 & $4.30-4.51$ \\
\hline $\begin{array}{l}\text { When presented with a problem I cannot resolve, I ask for } \\
\text { assistance }\end{array}$ & 4 & 3.73 & $3.55-3.90$ \\
\hline I like to evaluate what I do & 4 & 3.99 & $3.86-4.12$ \\
\hline I enjoy studying & 3 & 2.95 & $2.76-3.13$ \\
\hline I have a need to learn & 5 & 4.44 & $4.33-4.53$ \\
\hline I enjoy a challenge & 4 & 4.09 & $3.94-4.23$ \\
\hline I want to learn new information & 5 & 4.53 & $4.42-4.62$ \\
\hline I enjoy learning new information & 5 & 4.48 & $4.38-4.58$ \\
\hline I like to gather the facts before I make a decision & 4 & 4.13 & $4.02-4.24$ \\
\hline Self-control: & 4 & 4.15 & $4.07-4.22$ \\
\hline I am able to focus on a problem & 4 & 4.12 & $4.02-4.22$ \\
\hline I prefer to set my own learning goals & 4 & 4.15 & $4.02-4.27$ \\
\hline I am responsible & 4 & 4.28 & $4.16-4.40$ \\
\hline I have high personal expectations & 5 & 4.46 & $4.36-4.56$ \\
\hline I have high personal standards & 4 & 4.20 & $4.08-4.31$ \\
\hline I have high beliefs in my abilities & 4 & 4.33 & $4.22-4.45$ \\
\hline I am aware of my own limitations & 4 & 4.15 & $4.02-4.26$ \\
\hline I am logical & 4 & 4.20 & $4.09-4.32$ \\
\hline I evaluate my own performance & 4 & 3.95 & $3.81-4.08$ \\
\hline $\begin{array}{l}\text { I prefer to set my own criteria on which to evaluate my } \\
\text { performance }\end{array}$ & 4 & 3.79 & $3.65-3.92$ \\
\hline I am responsible for my own decisions/actions & 4 & 4.33 & $4.21-4.44$ \\
\hline I can find out information for myself & 4 & 3.90 & $3.78-4.03$ \\
\hline I like to make decisions for myself & 4 & 4.35 & $4.25-4.44$ \\
\hline I prefer to set my own goals & 4 & 4.33 & $4.22-4.44$ \\
\hline I am in control of my life & 4 & 3.66 & $3.48-3.85$ \\
\hline
\end{tabular}


Among the three subscales, "Self-control" got the highest mean score (4.15) followed by "Desire for Learning" (4.07), while "Self-management" got the lowest mean score (3.69). The mean total score for the students in SDL readiness was 159.25 (range: 117 to 193), with $76.2 \%$ of the students who got scores $\geq 150$ and $23.8 \%$ of them who got scores $<$ 150.

Females showed higher overall readiness score (161.20) than males (156.79), and also higher scores for all subscales. The differences were statistically significant $(p<0.05)$ for the overall readiness score and for "Desire for Learning" subscale (Table 3). 
Table 3: Scores of different sub-scales and overall readiness scale, with differences between males and females:

\begin{tabular}{|c|c|c|c|c|c|}
\hline & & $\begin{array}{c}\text { Self- } \\
\text { management } \\
\text { (out of 65) }\end{array}$ & $\begin{array}{l}\text { Desire for } \\
\text { Learning } \\
\text { (out of } 60 \text { ) }\end{array}$ & $\begin{array}{c}\text { Self- } \\
\text { control } \\
\text { (out of } 75)\end{array}$ & $\begin{array}{c}\text { Overall } \\
\text { SDL } \\
\text { Readiness } \\
\text { (out of } 200 \text { ) } \\
\end{array}$ \\
\hline \multirow{4}{*}{$\begin{array}{l}\text { Male } \\
(n=106)\end{array}$} & Mean & 47.25 & 48.21 & 61.34 & 156.79 \\
\hline & SD & 6.77 & 4.58 & 7.08 & 14.91 \\
\hline & Maximum & 60 & 58 & 75 & 187 \\
\hline & Minimum & 25 & 34 & 41 & 117 \\
\hline \multirow{4}{*}{$\begin{array}{l}\text { Female } \\
(n=133)\end{array}$} & Mean & 48.98 & 49.35 & 62.87 & 161.20 \\
\hline & SD & 6.78 & 4.29 & 6.47 & 13.88 \\
\hline & Maximum & 63 & 60 & 75 & 193 \\
\hline & Minimum & 20 & 40 & 45 & 132 \\
\hline \multicolumn{2}{|c|}{ Paired-sample t-test } & 1.96 & 1.98 & 1.74 & 2.36 \\
\hline \multicolumn{2}{|c|}{$\begin{array}{l}\text { Significance } \\
(p \text {-value })\end{array}$} & 0.051 & $0.048^{*}$ & 0.083 & $0.019^{*}$ \\
\hline \multirow{4}{*}{$\begin{array}{l}\text { Total } \\
(n=239)\end{array}$} & Mean & 48.21 & 48.85 & 62.19 & 159.25 \\
\hline & SD & 6.81 & 4.45 & 6.78 & 14.48 \\
\hline & Maximum & 63 & 60 & 75 & 193 \\
\hline & Minimum & 20 & 34 & 41 & 117 \\
\hline
\end{tabular}

* Statistically significant

Table 4 shows the linear regression analysis of the relationship between gender and GPA. After allowing for gender, increased GPA was associated with increased total score for SDLRS. This relationship was statistically significant $(p=0.021)$. This linear relationship between GPA and SDLRS score is shown in Fig. 1. 
Table 4: Regression analysis of the relationship between both Gender and GPA and the total score for SDL readiness:

\begin{tabular}{|c|c|c|c|c|c|c|}
\hline \multirow{2}{*}{$\begin{array}{l}\text { Dependent } \\
\text { Variable } \\
\text { (SDLRS Total } \\
\text { Score) }\end{array}$} & \multirow{2}{*}{$\begin{array}{l}\text { Independent } \\
\text { Variables }\end{array}$} & \multicolumn{2}{|c|}{$\begin{array}{c}\text { Unstandardized } \\
\text { Coefficients }\end{array}$} & \multirow{2}{*}{$\mathbf{t}$} & \multirow{2}{*}{$\mathbf{F}$} & \multirow{2}{*}{$\begin{array}{c}\text { Significance } \\
(p \text {-value })\end{array}$} \\
\hline & & B & SE & & & \\
\hline \multirow{2}{*}{$\begin{array}{l}\text { Total Score for } \\
\text { SDL Readiness }\end{array}$} & Gender & -0.276 & 2.627 & -0.105 & 1.183 & 0.916 \\
\hline & GPA & 4.913 & 2.107 & 2.332 & 6.694 & $0.021 *$ \\
\hline
\end{tabular}

SDL: Self-Directed Learning

GPA: Grade Point Average

Also, after allowing for GPA, no significant difference was found in the relationship between gender and overall mean score for SDLRS $(p=0.916)$.

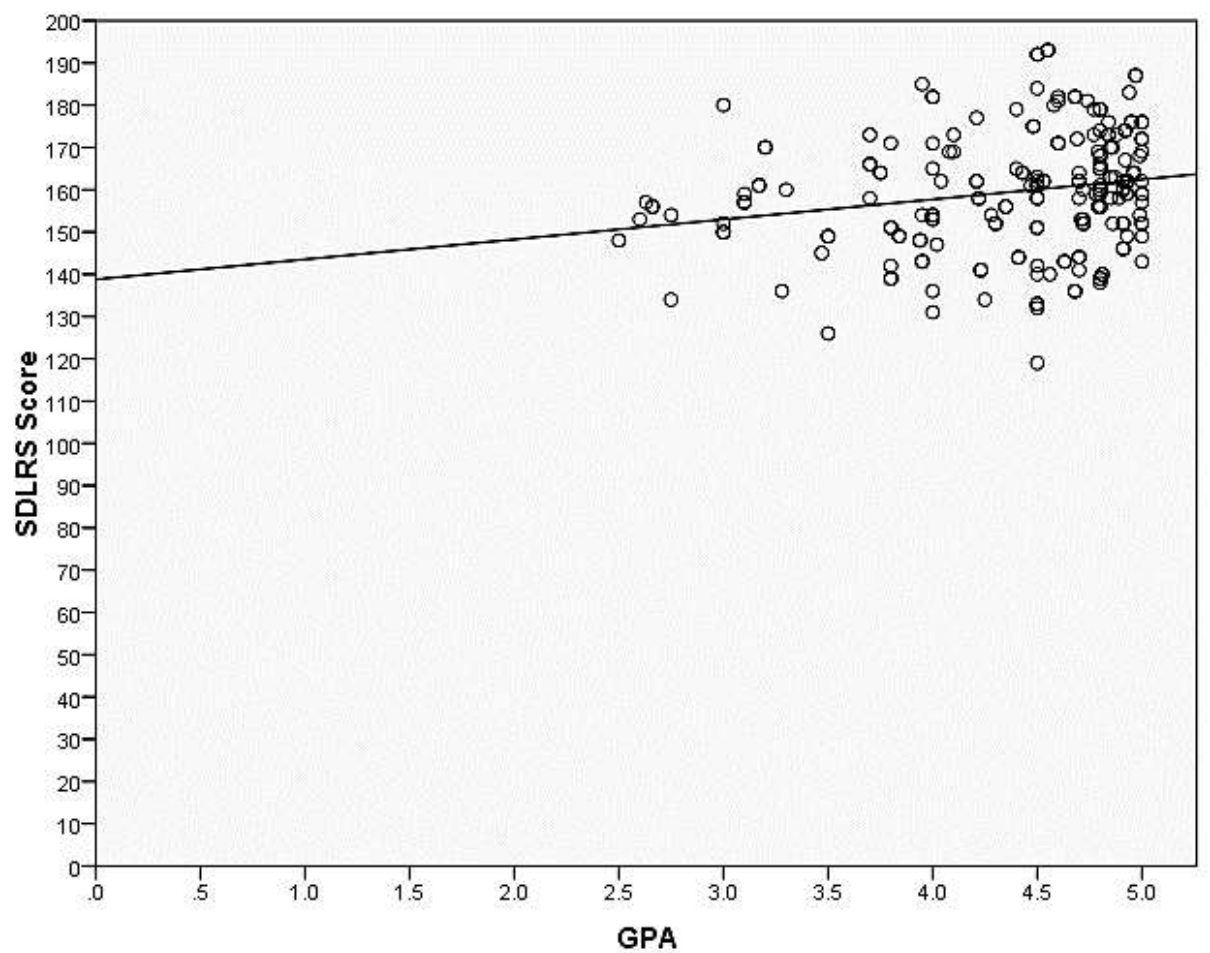

Fig. 1: Linear regression between GPA and overall SDLRS mean score 